\title{
STUDIES OF THE FEATURES OF THE SORPTION OF AN EUROPIUM BY NATURAL AND SYNTHETIC ZEOLITES FOR USING IT IN THE NUCLEAR ENERGY
}

\author{
V.V. Levenets, A.Yu. Lonin, O.P. Omelnik, A.O. Shchur \\ National Science Center "Kharkov Institute of Physics and Technology", Kharkiv, Ukraine \\ E-mail:a_lonin@kipt.kharkov.ua
}

\begin{abstract}
A technique of quantitative determination of europium by proton-induced X-ray emission (PIXE) using of 1.6 MeV energy and measurement of the characteristic europium $\mathrm{L}_{\alpha}$-shell X-rays is developed. The possibility of using carbon substrates for the preparation of europium targets to be subjected to $1.6 \mathrm{MeV}$ proton irradiation was studied. A linear dependence of the quantitative content and the emission intensity of the $\mathrm{L}_{\alpha}$-shell of europium is obtained. The use of europium as a natural analogue was applied to the study of the americium sorption from aqueous solutions by natural and synthetic zeolites under static conditions. It has been established that the europium sorption coefficient $\left(K_{s}\right)$ for clinoptilolite is $72.7 \%$ that is twice as high the $K_{s}$ for synthetic zeolites NaA $\left(K_{s}-\right.$ $36.8 \%)$ and $\mathrm{NaX}\left(K_{\mathrm{s}}-25.2 \%\right)$. The effect of competing sodium ions on europium sorption by zeolites has been studied.
\end{abstract}

\section{INTRODUCTION}

The accident at the Chernobyl nuclear power plant (CNPP) was in 1986. As a result of the accident, radioactive substances were released into the environment: uranium and plutonium isotopes, iodine131, cesium-134, cesium-137, strontium-90. Exclusion zone $(30 \mathrm{~km})$ was created around nuclear power plant. The lands that entered the exclusion zone were withdrawn from economic turnover. The half-lives of the main isotopes of cesium and strontium were cesium$137-30$ years and strontium- $90-28.8$ years. This led to the resolution of the problem of removing existing restrictions and reducing the exclusion zone, which did not take into account the problem of long-lived radionuclides, such as americium-241. At the time of the accident, the reactor also contained plutonium-241 $(50 \mathrm{~kg})$, whose decay product is americium- 241 .

$$
{ }^{241} \mathrm{Pu} \beta \text {-decay } \rightarrow{ }^{241} \mathrm{Am} \text {. }
$$

The half-lives of plutonium-241 and americium-241 are 13.2 and 432.2 years, respectively $[1,2]$. The situation with the spread of ${ }^{241} \mathrm{Am}$ as a result of the accident at CNPP acquired threatening consequences. ${ }^{241} \mathrm{Am}$ was discovered not only in the territory of Ukraine, but also in the territory of Russia and Finland [3]. The ratio of isotope activities ${ }^{241} \mathrm{Am} /{ }^{239+240} \mathrm{Pu}$ increases every year. Such a ratio was $0.13 \pm 0.03$ in 1986. According to the literature for the period 1986-2059 after the accident at the CNPP as a result of radioactive decay of ${ }^{241} \mathrm{Pu}$, the ${ }^{241} \mathrm{Am}$ content in the atmosphere will increase by 40 times [4].

The americium-241 emits alpha particles and soft (60 keV) gamma-rays in decay. The americium-241 has a fairly good solubility and great mobility in the environment when compared with plutonium [1].

Americium is highly radiotoxic. The maximum permissible concentration for americium in water bodies is about $70 \ldots 80 \mathrm{~Bq} / 1$ [1]. Americium is accumulated in the human body primarily in the bones. In consideration of the aforementioned concerns, the issues of sorption of americium and its removal from the environment are matters of prime importance.
The problems of americium sorption are very relevant and are widely considered in modern publications [5-8]. In particular, sorption of americium by montmorillonite from groundwater was studied. The effect of $\mathrm{pH}$ on sorption processes was studied: sorption and ion exchange at low $\mathrm{pH}$, complexation at high $\mathrm{pH}$ [5]. The study examined the mobility of americium in tropical and European soils, as well as in groundwater. The strong effect of organic additives on the mobility of americium has been established [7].

Sorption of americium by zeolites requires further study. Sorption properties of zeolites, sorption mechanisms, exchange capacities were studied in a monograph D.W. Breck [9].

Since americium-241 is toxic, work with it requires special equipment, staff training and the presence of permissive documents from government controlling bodies.

According to Seaborg theory [10], americium shows similar chemistry with europium. Therefore, europium can be used as a chemical analogue to americium for laboratory studies.

The aim of the work is the comparison of the sorption properties of zeolites (natural and synthetic) with respect to europium ions, as well as the development of a method for quantitative determination of europium with proton-induced X-ray emission (PIXE), using a $1.6 \mathrm{MeV}$ proton beam.

The PIXE method allows to conduct elemental analysis without destroying the object of research and to give a quantitative assessment, as reflected in a number of publications $[11,12]$. This method is important when working with micro quantities of a researched substance.

An important stage of research is the comparison of the sorption properties of natural zeolite (clinoptilolite) and synthetic zeolites. This is the basis for the subsequent use of the composition based on natural and synthetic zeolites in nuclear energy. Differences in the structure of the zeolites under consideration affect their sorption properties. Clinoptilolite has a ratio of $\mathrm{SiO}_{2} / \mathrm{Al}_{2} \mathrm{O}_{3}=4-10$, and the synthetic zeolites discussed 
in this paper have a ratio of $\mathrm{SiO}_{2} / \mathrm{Al}_{2} \mathrm{O}_{3}=2-3$. This significantly affects the number of exchange centers in the structure of zeolite [9].

It is necessary to take into account that in natural zeolite of this mineral group there are several modifications, depending on the place of extraction and depth. This can have a significant effect on the change in elemental composition, what directly affects the change in the sorption properties of zeolite. So according to the data of the American Mineralogical Society, there are 17 modifications of clinoptilolite [13].

\section{METHODS AND OBJECTS OF RESEARCH}

\subsection{OBJECTS OF RESEARCH}

Natural and synthetic zeolites were used in the work. The natural zeolite - clinoptilolite (Sokyrnitsky deposit, Transcarpathian region, Ukraine) refers to high-silicon zeolites. Ukraine has a large clinoptilolite deposit. Clinoptilolite deposits are located in different countries: USA, Turkey, Armenia, Georgia, Bulgaria, etc. Synthetic zeolites $\mathrm{NaX}$ and $\mathrm{NaA}$ (Salavat Catalyst Plant, Russia) refers to low-silicon zeolites. Zeolites were preliminarily ground to increase the contact surface of the sorbent with the solution.

\subsection{SORPTION OF EUROPIUM IN STATIC CONDITIONS}

In this work, europium oxide (III) $-\mathrm{Eu}_{2} \mathrm{O}_{3}$ was used. The europium in this compound was in a stable state. The solution was prepared as follows: a portion of europium oxide weighted on analytical scales was placed in a volumetric flask of capacity $100 \mathrm{ml}$, was dissolved in $50.0 \mathrm{ml}$ of $0.01 \mathrm{M}$ hydrochloric acid, and then, after dissolution, the volume of solution was brought to the mark with distilled water. The content of europium in the solution was $80.00 \mathrm{mg} / \mathrm{ml}$.

Sorption was carried out under static conditions according to the following method: a portion of a sorbent with a mass of $0.05 \mathrm{~g}$ was placed in a $100 \mathrm{ml}$ flask containing $10 \mathrm{ml}$ of europium solution, which was measured with a burette.

The phase ratio in the experiment (liquid-sorbent) was $-200: 1$. The solution was periodically mixed and samples were taken to determine the sorption interaction in the solution-sorbent system. To completely separate the sorbent and solution, the samples were centrifuged for $5 \mathrm{~min}$ at a speed of $3000 \mathrm{rpm}$. The experiment was carried out in static conditions for $96 \mathrm{~h}$.

To model the presence of competing ions, sodium chloride was added to the solution at appropriate concentrations of 0.0002 and $0.0004 \mathrm{~g} / \mathrm{ml}$.

\subsection{PREPARATION OF TARGETS}

The preparation of the targets was carried out according to the following technique: $0.05 \mathrm{ml}$ of solutions containing europium were applied to carbon substrates and dried under heating to $35^{\circ} \mathrm{C}$. A carbon matrix $10.0 \mathrm{~mm}$ long and $2.0 \mathrm{~mm}$ thick was used in the preparation of targets. The distribution of the solution during drying took place over the surface layers of the carbon matrix.

\subsection{ANALYTICAL PART. QUANTITATIVE DETERMINATION OF EUROPIUM IN SAMPLES}

The analytical part of the work was performed on the analytical nuclear-physical complex "Sokol" [1417]. The main part of the complex is the Van de Graaff electrostatic accelerator. The energy range of the electrostatic accelerator is $200 \ldots 2000 \mathrm{keV}$. The maximum ion current at the direct output of the magnetic analyzer is $30 \mu \mathrm{A}$. The diameter of the ion beam on the target varies from $3 \mu \mathrm{m}$ to $5 \mathrm{~mm}$. The complex makes it possible to realize all the basic methods of analysis on ion beams and irradiate the investigated object with one and two-charged ions of gases from hydrogen to xenon.

Europium was excited by a proton beam with an energy $E p \approx 1600 \mathrm{keV}$, an average current $I p \approx 150 \mathrm{nA}$ [14-17].

For measuring the proton charge, the chamber was used as a Faraday cup. The irradiation of the samples was carried out in a vacuum under pressure $10^{-4} \mathrm{~Pa}$. The emitted X-rays entered the X-ray detector through a beryllium window $25 \mu \mathrm{m}$ thickness. Registration of the excited characteristic X-ray emission of L-series of europium atoms was carried out using detector XR100CR Si-PIN X-Ray. The detector was installed at an angle of $135^{\circ}$ with respect to the proton beam, before beryllium foil windows [17].

XR-100CR Si-PIN X-Ray detector with a resolution of $163 \mathrm{eV}$ along line $5.9 \mathrm{keV}$ was located at a distance of $7 \mathrm{~cm}$ from the target (Fig. 1). The thickness of the detector crystal was $500 \mu \mathrm{m}$, the working surface area $6 \mathrm{~mm}^{2}$ and the thickness of the foil of the entrance window $-12.5 \mu \mathrm{m}$ beryllium. The counting efficiency of europium L-lines was close to $100 \%$. X-ray radiation was collimated by a diaphragm of $2.5 \mathrm{~mm}$ diameter. A mylar absorber $150 \mu \mathrm{m}$ in thickness was placed in front of the detector. The measurement time was $45 \mu \mathrm{C}$.

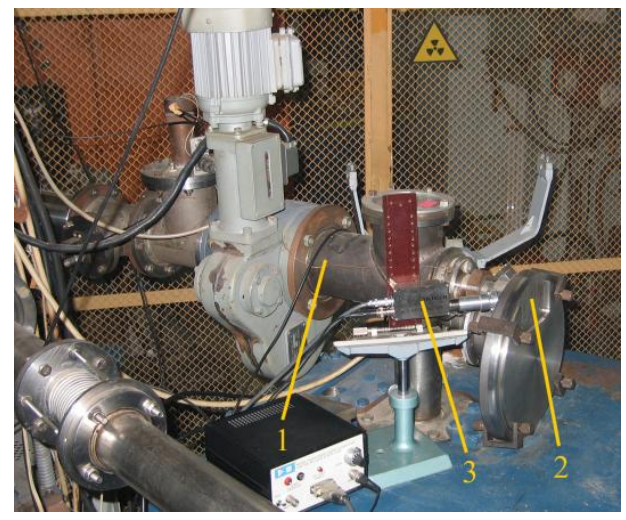

Fig. 1. Arrangement of the detectors relative to the proton beam and the target chamber: 1 - proton beam; 2 - target chamber; 3 -XR-100CR Si-PIN X-Ray detector

\section{RESULTS AND DISCUSSION}

Typical view of the characteristic X-ray spectrum of europium L-lines measured in the conditions mentioned above is shown in Figs. 2, 3.

The spectrum of the carbon matrix with a dry residue of hydrochloric acid and the the spectrum of 
target with a minimum amount of europium $(0.05375 \mathrm{mg})$ are presented in Fig. 2.

The characteristic X-ray emission of europium $\mathrm{L}_{\alpha}$ and $\mathrm{L}_{\beta 1}$-lines was used for identification and quantitative determination. It was found that the carbon matrix with a dry residue of hydrochloric acid contains lines which prevent the definition of europium $\mathrm{L}_{\beta 1}$-line. Europium $\mathrm{L}_{\alpha}$-line can be used to determine, because a carbon matrix with a dry residue of acid hydrochloric does not contain lines which interfere with the analysis.

The presence of impurities in the spectrum of hydrochloric acid is due to the composition of the carbon matrix. The carbon matrix composition was discussed in more detail in a previous publication [16].

The characteristic X-ray emission of carbon target with a content of europium $4.0762 \mathrm{mg}$ is presented in Fig. 3. This spectrum makes it possible to estimate the maximum amount of europium studied in the work.

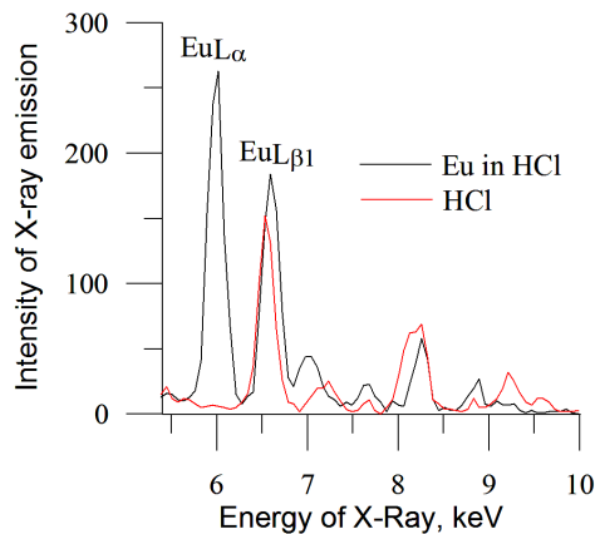

Fig. 2. Spectra of characteristic $X$-ray emission of carbon target with a dry residue of hydrochloric acid and carbon target with $0.05375 \mathrm{mg}$ of europium

$\left(E_{p}=1600 \mathrm{keV}, I_{p}=200 \mathrm{nA}, Q_{p}=45 \mu \mathrm{C}\right)$.

- Eu in $\mathrm{HCl}$ - spectrum of characteristic X-ray emission of carbon target which contains europium in a solution of hydrochloric acid;

- $\mathrm{HCl}$ - spectrum of characteristic X-ray emission of carbon target with a dry residue of hydrochloric acid

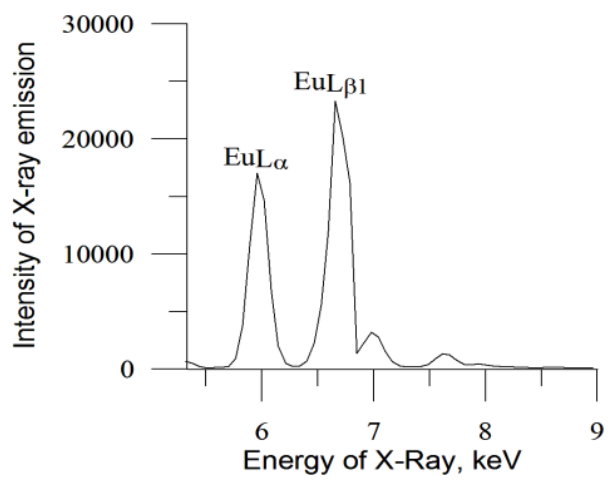

Fig. 3. Spectrum of characteristic $X$-ray emission of a carbon target containing $4.0762 \mathrm{mg}$ europium $\left(E_{p}=1600 \mathrm{keV}, I_{p}=200 \mathrm{nA}, Q_{p}=45 \mu \mathrm{C}\right)$ :

- Eu in $\mathrm{HCl}$ - spectrum of characteristic X-ray emission of carbon target which contains europium in a solution of hydrochloric acid
Processing of the spectra was performed using a code WinQXAS: a program for X-ray absorption spectroscopy [18].

The thermal effect of protons on the change in europium content in the target was considered in the course of research. Targets with a europium content of $0.9739 \mathrm{mg}$ were subjected to a prolonged irradiation with a proton beam with periodic measurements of the output of characteristic europium X-rays.

The obtained data (Table 1) indicated that the targets from the dry residue of the solution of europium on the carbon substrate withstood a multiple impact of the proton beam with the retention of the specific output of the analytical radiation.

The loss of the substance from the substrate was absent, which indicated a strong bond between europium and target due to the sorption interaction of the solution and the substrate during the application of the solution and drying of the target. The temperature of the sample measured during irradiation with an infrared pyrometer did not exceed $100{ }^{\circ} \mathrm{C}$.

Table 1

The influence of the dose the proton irradiation on the yield (Y) $\mathrm{L}_{\alpha}-\mathrm{X}$-ray emission from the target $(n=4, P=95 \%)$

\begin{tabular}{|c|c|c|}
\hline No & $\begin{array}{c}\text { Y, L- } \\
\text { emission } \\
\text { intensity of } \\
\text { europium }\end{array}$ & Metrological characteristics \\
\hline 1 & 13772.5 & \multirow{4}{*}{$\begin{array}{cc}\bar{X}=13767.15 & S^{2}=448.68 \\
S=21.18 & S \bar{x}=10.59 \\
\Delta \bar{x}=33.70 \quad R S D \bar{x}=0.075 \\
\bar{\varepsilon}=0.24 \\
\bar{X} \pm \Delta \bar{x}=13767.15 \pm 33.70\end{array}$} \\
\hline 2 & 13739.2 & \\
\hline 3 & 13790.3 & \\
\hline 4 & 13766.6 & \\
\hline
\end{tabular}

As a result of the experiment, the dependence of the radiation intensity of europium $\mathrm{L}_{\alpha}$-line as a function of the collection time was studied (Fig. 4). The time of spectrum collection was determined from the value of the charge measured in $\mu \mathrm{C}$ units. Target stability in the presence of the heat from the beam was investigated by assessing beam charge collected across increasing beam intensity. A linear relationship indicated that the target was highly stable without experiencing decomposition in the presence of the beam.

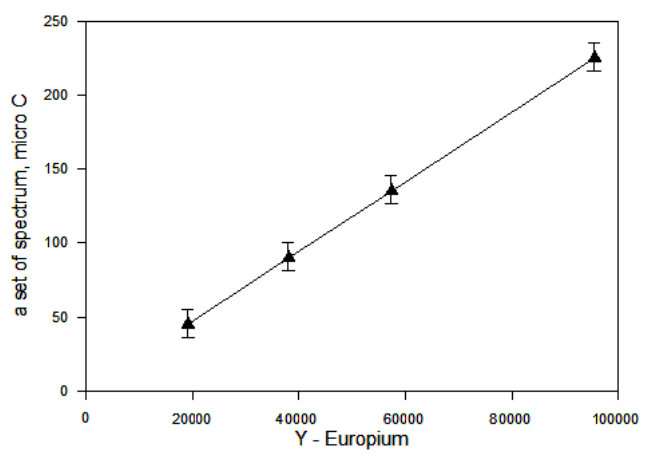

Fig. 4. Dependence of the intensity of europium $L_{\alpha}$-line on the proton charge for the target containing $1.3510 \mathrm{mg}$ of europium 
For the quantitative determination of europium, a graph of the dependence of the content of europium in the target $(0.05375 \ldots 4.0762 \mathrm{mg})$ from the $\mathrm{X}$-ray intensity of the $\mathrm{L}_{\alpha}$-line was plotted (Fig. 5). According to the graph, the linear dependence of the europium concentration on the radiation intensity was established throughout the concentration range.

The obtained dependence of the content of europium in the target $(0.05375 \ldots 4.0762 \mathrm{mg})$ from the X-ray intensity of the $\mathrm{L}_{\alpha}$-line can be used in the work for determining the content of europium in the solutions under study in carrying out various experiments, as well as to control the content of europium in aqueous solutions of various origins.

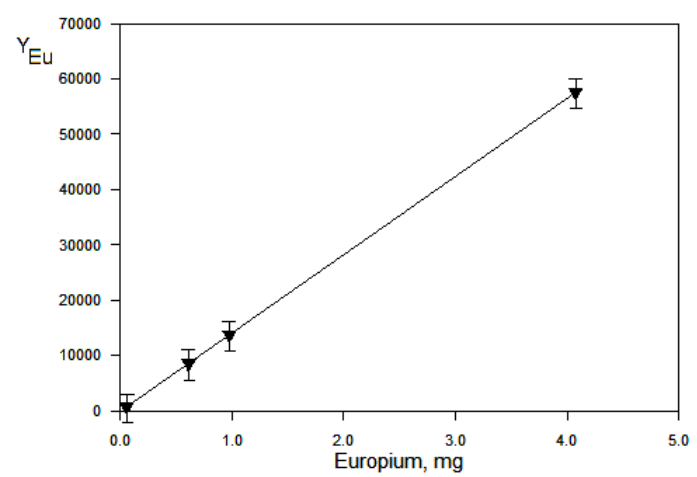

Fig. 5. Dependence of the content of europium on the intensity of its $L_{\alpha}$-line

The total error in the determination of europium in the analyzed samples was between 6.0 and 1.5 weight percents. It was composed of error in the determination of europium $\mathrm{L}_{\alpha}$-line intensity, error of proton charge measurement, and the error in the preparation of the samples.

For the quantitative characteristics of the sorption interaction of zeolites with europium were used the distribution coefficient $\left(K_{\mathrm{d}}, \quad \mathrm{ml} / \mathrm{g}\right)$ and sorption coefficient $\left(K_{\mathrm{s}}, \%\right)$, which were calculated by as:

$$
\begin{aligned}
& K_{d}=\frac{\left(C_{0}-C_{p}\right) \cdot V}{C_{p} \cdot m}, \\
& K_{s}=\frac{\left(C_{0}-C_{p}\right) \cdot 100 \%}{C_{0}},
\end{aligned}
$$

where $C_{\mathrm{o}}$ and $C_{\mathrm{p}}$ are the initial and equilibrium concentration of the solution in $\mathrm{mg} / \mathrm{ml} ; V$ is the volume of solution in $\mathrm{ml} ; m$ is the mass of sorbent in $\mathrm{g}$.

On the basis of the dependence of the sorption coefficients from the contact time of the sorbent with the europium solution, kinetic curves are constructed. Kinetic curves made it possible to determine the onset of sorption equilibrium in the zeolite-europium solution (Fig. 6).

The ion exchange of europium in zeolites consists of two stages - fast and slow. The fast sorption stage for clinoptilolite is $5 \mathrm{~h}$. At this stage, the sorption coefficient increases from 0 to $5.9 \%$. For synthetic zeolites, the fast stage is $3 \mathrm{~h}$. The change in the sorption coefficient is for NaA zeolite from 0 to $19.8 \%$, and for $\mathrm{NaX}$ zeolite from 0 to $16.8 \%$.
After $96 \mathrm{~h}$ of sorption, $K_{\mathrm{s}}$ of clinoptilolite for europium was $72.7 \%$, which significantly exceeds the sorption properties of synthetic zeolites for europium $\left(\mathrm{K}_{s}(\mathrm{NaA})-36.8 \%, \mathrm{~K}_{s}(\mathrm{NaX})-25.2 \%\right)$. As a result of the experiment it was found that clinoptilolite has a high selectivity to europium, which is due to the peculiarities of the structure of the crystal lattice of natural zeolite. The introduction of sodium ions leads to a significant reduction in the sorption properties of zeolites with respect to europium. The data are presented in Table 2 .

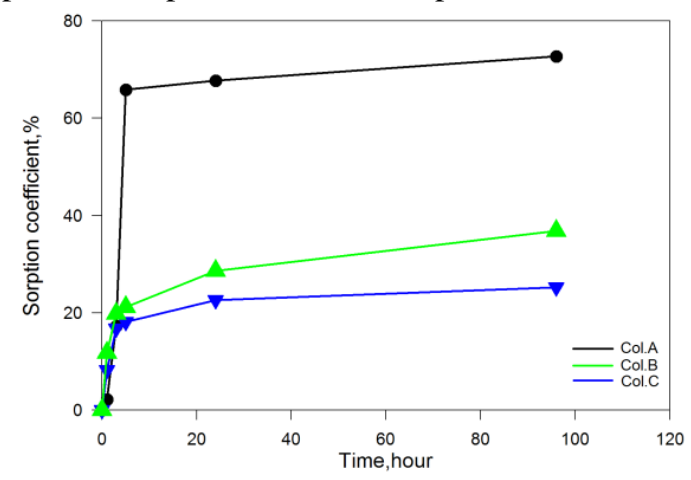

Fig. 6. Kinetic curves of europium sorption by zeolites:

$A$ - sorption curve of europium by clinoptilolite;

$B$ - sorption curve of europium by zeolite $\mathrm{NaA}$;

$C$ - sorption curve of europium by zeolite $\mathrm{NaX}$

Table 2

The effect of sodium chloride on the sorption coefficient $\left(K_{\mathrm{s}}, \%\right)$ of europium by zeolites

\begin{tabular}{|c|c|c|c|}
\hline $\begin{array}{c}\text { Sorption } \\
\text { coefficient }\left(K_{\mathrm{s}}, \%\right) \\
\text { of europium by } \\
\text { zeolites }\end{array}$ & \multicolumn{3}{|c|}{$\begin{array}{c}\text { Content of sodium chloride } \\
\text { in solution, g/ml }\end{array}$} \\
\cline { 2 - 4 } & 0 & 0.0002 & 0.0004 \\
\hline Clinoptilolite & 72.7 & 47.5 & 34.6 \\
\hline Zeolite $\mathrm{NaA}$ & 36.8 & 25.9 & 20.7 \\
\hline Zeolite $\mathrm{NaX}$ & 25.2 & 17.4 & 14.5 \\
\hline
\end{tabular}

The values of the distribution coefficients $\left(K_{\mathrm{d}}, \mathrm{ml} / \mathrm{g}\right)$ for all considered zeolites are presented in Table 3 . The distribution coefficients were determined at the end of the sorption experiment (after reaching sorption equilibrium, which was established after $96 \mathrm{~h}$ of sorption). The highest $K_{\mathrm{d}}$ values were found for clinoptilolite $\left(K_{\mathrm{d}}-531.5 \mathrm{ml} / \mathrm{g}\right)$. It was also found that the presence of competing ions has the strongest effect on reducing the sorption properties of clinoptilolite, which is due to the structural characteristics of clinoptilolite. Clinoptilolite refers to zeolites with a high silicon content, which affects the number of exchange sites. Clinoptilolite has a complex composition of exchangeable ions.

As a result of comparing the sorption properties of natural and synthetic zeolites, it was established that clinoptilolite is the most effective for removing europium from solutions. With the further use of clinoptilolite for europium sorption, it is necessary to take into account the effect of competing ions that may be present in the solution. For effective application of clinoptilolite, the following can be recommended:

- reduction of the content of competing sodium ions in solution by additional dilution, which leads to an 
increase in the volume of the solution and, correspondingly, to an increase in the sorbent used;

- use of a battery of sorption reactors for maximum solution purification (Fig. 7) [17]. Using a sorption system from several sorption reactors makes it possible to maximally reduce the concentration of europium in solution.

Values of the distribution coefficient $\left(K_{\mathrm{d}}, \mathrm{ml} / \mathrm{g}\right)$

Table 3 of europium in zeolites

\begin{tabular}{|c|c|c|c|}
\hline $\begin{array}{c}\text { Distribution } \\
\text { coefficient }\left(K_{\mathrm{d}}, \mathrm{ml} / \mathrm{g}\right) \\
\text { of europium } \\
\text { in zeolites }\end{array}$ & \multicolumn{3}{|c|}{$\begin{array}{c}\text { Content of sodium chloride } \\
\text { in solution, } \mathrm{g} / \mathrm{ml}\end{array}$} \\
\cline { 2 - 4 } & 0 & 0.0002 & 0.0004 \\
\hline Clinoptilolite & 531.5 & 347.3 & 253.0 \\
\hline Zeolite $\mathrm{NaA}$ & 269.0 & 189.4 & 151.3 \\
\hline Zeolite $\mathrm{NaX}$ & 184.2 & 127.2 & 106.0 \\
\hline
\end{tabular}

A similar scheme was proposed when considering the sorption of strontium by zeolites [17]. The use of zeolites as a sorbent for europium will allow the formation of a matrix for subsequent disposal as a solid waste.

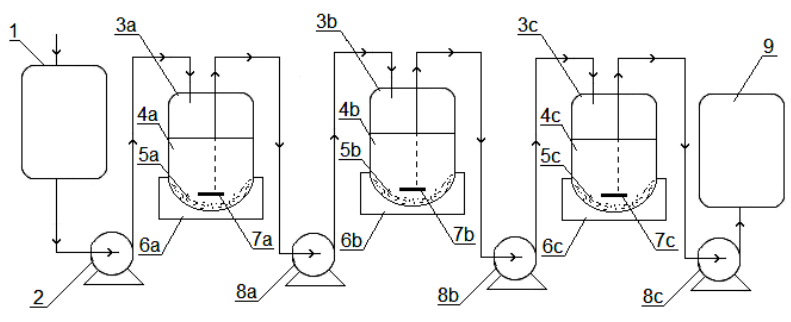

Fig. 7. Scheme of the sorption installation consisting of a battery of sorption columns:

1 - collection with the initial solution that contains europium; 2 - pump for supplying the initial solution;

$3 a, 3 b, 3 c-$ glass reactors for sorption;

$4 a, 4 b, 4 c-$ solution in the reactor;

$5 a, 5 b, 5 c-$ sorbent (zeolite); $6 a, 6 b, 6 c$-magnetic stirrer; 7a, 7b, 7c-magnet; $8 a, 8 b, 8 c$-pumps for draining liquids after sorption; 9 - collection of solution after sorption [17]

The results were correlated in accordance with the Pearson equation. The correlation allows us to more accurately confirm the similarity of the sorption properties of zeolites, which are considered in the work. This is important, because zeolites with different silicon content are used in the work, which significantly affects the sorption properties. To use the Pearson equation, the zeolites were compared pairwise. The correlation coefficient allows to determine the statistical relationship between the values of sorption for different zeolites. When the value of the correlation coefficient tending to 1, one can argue about the existence of strong functional relationships within the system under consideration, consisting of a group of two quantities. Determination of the correlation coefficient was carried out according to the formula:

$$
R_{X, Y}=\frac{\sum_{i=1}^{m}\left(X_{i}-\bar{X}\right)\left(Y_{i}-\bar{Y}\right)}{\sqrt{\sum_{i=1}^{m}\left(X_{i}-\bar{X}\right)^{2} \sum_{i=1}^{m}\left(Y_{i}-\bar{Y}\right)^{2}}},
$$

where $\bar{X}, \bar{Y}$ - selective averages $X_{m}$ (results of zeolite sorption - 1) and $Y_{m}$ (results of zeolite sorption - 2). The obtained values of the correlation coefficient, presented in Table 4 show the dependence in each of the considered groups. This confirms the fact that, despite the existing differences in the structure of zeolites they have a single sorption mechanism.

Table 4

The values of the correlation coefficient for the considered group of zeolites

\begin{tabular}{|c|c|}
\hline The group of zeolites & Correlation coefficient \\
\hline NaA zeolite - NaX zeolite & 0.9984 \\
\hline NaX zeolite - Clinoptilolite & 0.9972 \\
\hline NaA zeolite - Clinoptilolite & 0.9998 \\
\hline
\end{tabular}

\section{CONCLUSIONS}

A technique of quantitative determination of europium by PIXE using protons of $1.6 \mathrm{MeV}$ energy and detecting characteristic europium $\mathrm{L}_{\alpha}$-line $\mathrm{X}$-rays was developed. The method allowed to determine the content of europium in small quantities at high reliability of measurements, carry out repeated and comparative measurements. The technique can be used in model experiments.

As a result of the research, the sorption properties of zeolites (natural and synthetic zeolites) in relation to europium - imitator of americium, were compared. It was found that clinoptilolite (natural zeolite) showed the highest selectivity with respect to europium. The sorption coefficient of clinoptilolite was $72.7 \%$, which was twice the sorption coefficient of synthetic zeolites $\left(K_{\mathrm{s}}(\mathrm{NaA})-36.8 \%, K_{\mathrm{s}}(\mathrm{NaX})-25.2 \%\right)$. The influence of the presence of competing sodium ions on europium sorption by zeolites was determined. The presence of competing ions led to a decrease in the sorption coefficient. As a result of research, a scheme of using zeolites for maximum solution purification was proposed.

The data obtained on comparing the sorption properties of clinoptilolite and synthetic zeolites allowed to expand the possibilities of using zeolites in nuclear energy. Zeolites can be used independently and in the form of a composition. Compositions based on clinoptilolite and synthetic zeolites can be used as the basis for cleaning decontaminants.

\section{REFERENCES}

1. V.A. Bazhenov, L.A. Buldakov, I.Ya. Vasilenko. Harmful chemicals. Radioactive substances: Ref. Ed. Chemistry. Leningrad, 1990, 464 p.

2. INSAG-7. The Chernobyl Accident: Updating of INSAG-1. IAEA, Vienna, 1992.

3. Jukka Lehto. Americium in the Finnish environment // Boreal environment research. 2009, N 14, p. 427-437. 
4. M.F. Kozhevnikova, V.V. Levenets, I.L. Rolik, A.A. Shchur. The radioactive contamination territory of Ukraine by $\mathrm{Pu}$ and ${ }^{241} \mathrm{Am}$ radionuclides due to the Chernobyl accident // Problems of Atomic Science and Technology. 2017, N 3(109), p. 26-30.

5. S. Kumar, A.S. Pente, R.K. Bajpai, C.P. Kaushik, B.S. Tomar. Americium sorption on smectite-rich natural clay from granitic ground water // Applied Geochemistry. 2013, N 35, p. 28-34.

6. K. Bhagyashree, Aishwarya Kar, Sharayu Kasar, Sumit Kumar, R. Shukla, R.K. Mishra, C.P. Kaushik, A.K. Tyagi, B.S. Tomar. Sorption of americium from low-level liquid wastes by nanocrystalline $\mathrm{MnO}_{2}$ // J. Radioanal Nucl. Chem. 2014, N 299, p. 1433-1437.

7. M.A.V. Wasserman, T.R. Pereira, E.R.R. Rochedo, W.O. Sousa, D.V. Pérez, E.F.M. Pinheiro, and F.F.L. Simões Filho. The influence of Brazilian soils properties in Americium sorption // Radioprotection. 2011, N 6, p. 579-585.

8. G. Lujanienè, P. Beneš, K. Štamberg, T. Ščiglo. Kinetics of plutonium and americium sorption to natural clay // Journal of Environmental Radioactivity. 2012, N 108, p. 41-49.

9. D.W. Breck. Zeolite Molecular Sieves: Structure, Chemistry, and Use. Wiley, New York, 1974, 606 p.

10. B.V. Gromov, V.I. Saveliev, I.B. Shevchenko. Chemical technology of irradiated nuclear fuel. M.: "Energoatomizdat", 1983, 352 p.

11. T.B. Johansson, G. Akselsson, S.A.E. Johansson. X-ray analysis: Elemental trace analysis at the $10^{-12} \mathrm{~g}$ level // Nuclear Instruments Methods. 1970, N 84, p. 141-145.
12. K. Sera, S. Futatsugawa, K. Matsuda, Y. Miura. Standard-free method of quantitative analysis for biosamples // International Journal of PIXE. 1996, N 6, p. 467-481.

13. American Mineralogist Crystal Structure Database. http://rruff.geo.arizona.edu/AMS/result.php.

14. A.Yu. Lonin, V.V. Levenets, I.M. Neklyudov, A.O. Shchur. The usage of zeolites for dynamic sorption of cesium from waste waters of nuclear power plants // J. Radioanal Nucl. Chem. 2015, N 303, p. 831-836.

15. V.V. Levenets, A.Yu. Lonin, O.P. Omelnik, A.O. Shchur. PIXE in the studies of stable cesium sorption from water solutions // X-Ray Spectrometry. 2015, N 44, p. 447-450.

16. V.V. Levenets, A.Yu. Lonin, O.P. Omelnik, A.O. Shchur. Comparison the sorption properties of clinoptilolite and synthetic zeolite during sorption strontium from the water solutions in static conditions: Sorption and quantitative determination of strontium by the method PIXE // Journal of Environmental Chemical Engineering. 2016, N 4, p. 3961-3966.

17. A.Yu. Lonin, V.V. Levenets, O.P. Omelnik, A.O. Shchur. Comparison of the sorption properties of natural and synthetic zeolites for the purification of aqueous solutions from cobalt: sorption of the cobalt from aqueous solutions in dynamic conditions and the quantitative determination of cobalt by the PIXE method // J. Radioanal Nucl. Chem. 2018, N 315, p. 163-169.

18. T. Ressler. WinXAS: a Program for X-ray Absorption Spectroscopy Data Analysis under MSWindows // Journal of Synchrotron Radiation. 1998, N 5, p. 118-122.

Статья поступила в редакциию 17.10.2019 2.

\section{ИССЛЕДОВАНИЯ ОСОБЕННОСТИ СОРБЦИИ ЕВРОПИЯ ПРИРОДНЫМ И СИНТЕТИЧЕСКИМИ ЦЕОЛИТАМИ ДЛЯ ИСПОЛЬЗОВАНИЯ В ЯДЕРНОЙ ЭНЕРГЕТИКЕ}

\section{В.В. Левенец, А.Ю. Лонин, А.П. Омельник, А.А. Щур}

Разработана методика количественного определения европия с помощью протон-индуцированного рентгеновского излучения (ХРИ) с использованием энергии 1,6 МэВ и регистрацией характеристического рентгеновского излучения $\mathrm{L}_{\alpha}$-оболочки европия. Изучена возможность использования углеродных подложек для приготовления мишеней, содержащих европий, для облучения протонами с энергией 1,6 МэВ. Получена линейная зависимость количественного содержания и интенсивности излучения $\mathrm{L}_{\alpha}$-оболочки европия. Исследована сорбция европия как имитатора америция из водных растворов природным и синтетическими цеолитами в статических условиях. Установлено, что коэффициент сорбции европия $\left(K_{\mathrm{s}}\right)$ для клиноптилолита составляет $72,7 \%$, что в два раза выше $K_{\mathrm{s}}$ для синтетических цеолитов $\mathrm{NaA}\left(K_{\mathrm{s}}-36,8 \%\right)$ и $\mathrm{NaX}\left(K_{\mathrm{s}}-25,2 \%\right)$. Изучено влияние конкурирующих ионов натрия на сорбцию европия цеолитами.

\section{ДОСЛІДЖЕННЯ ОСОБЛИВОСТІ СОРБЦІЇ ЄВРОПІЮ ПРИРОДНИМ ТА СИНТЕТИЧНИМИ ЦЕОЛІТАМИ ДЛЯ ВИКОРИСТАННЯ В ЯДЕРНІЙ ЕНЕРГЕТИЦІ}

\section{В.В. Левенець, О.Ю. Лонін, О.П. Омельник, А.О. Щур}

Розроблено методику кількісного визначення європію за допомогою протон-індукованого рентгенівського випромінювання (XРВ) з використанням енергії 1,6 МеВ і реєстрацією характеристичного рентгенівського випромінювання $\mathrm{L}_{\alpha}$-оболонки європію. Вивчено можливість використання вуглецевих підкладок для приготування мішеней, що містять європій для опромінення протонами з енергією 1,6 МеВ. Отримана лінійна залежність кількісного вмісту та інтенсивності випромінювання $\mathrm{L}_{\alpha}$-оболонки європію. Досліджена сорбція європію як імітатора америцію з водних розчинів природним і синтетичними цеолітами в статичних умовах. Встановлено, що коефіцієнт сорбції європію $\left(K_{\mathrm{s}}\right)$ для кліноптилоліту становить $72,7 \%$, що в два рази вище $K_{\mathrm{s}}$ для синтетичних цеолітів $\mathrm{NaA}\left(K_{\mathrm{s}}-36,8 \%\right)$ і $\mathrm{NaX}\left(K_{\mathrm{s}}-25,2 \%\right)$. Вивчено вплив конкуруючих іонів натрію на сорбцію європія цеолітами. 